4 Thornton JR, Losowsky MS. Plasma methionine enkephalin concentration and prognosis in primary biliary cirrhosis. Br Med f 1988;297:1241-2.

5 Thornton JR, Losowsky MS. Plasma leucine enkephalin is increased in liver disease. Gut 1988:29:A1429.

6 Thornton JR, Losowsky MS. A role for the kidneys and liver in plasma beta-endorphin elimination? Clin SCi 1988;74(suppl 18):51P

7 Michel ME, Bolger G, Weissman B-A. Binding of a new opiate antagonist, nalmefene, to rat brain membranes. Methods Find Exp Clin Pharmaco $1985 ; 7: 175-7$

8 Gal TJ, DiFazio CA, Dixon R. Prolonged blockade of opioid effect with ora nalmefene. Clin Pharmacol Ther 1986;40:537-42.

9 Gold MS, Redmond DE, Kleber HD. Clonidine blocks acute opiatewithdrawal sumptoms. Lancet 1978;ii:599-602.

10 Washton AM, Resnick RB. Clonidine for opiate detoxification. Out-patien clinical trials. A $m$ f Psychiatry 1980;137:1121-2.

11 Charnev DS, Heninger GR, Kleber HD. The combined use of clonidine and naltrexone as a rapid, safe and effective treatment of abrupt withdrawal from methadone Am $\mathcal{A}$ Psychiutry 1986:143:831-7.

12 Willet IR, Esler A1 Jennings G, Dudley FJ. Sympatheric tone modulates portal venous pressure in alcoholic cirrhosis. Lancet 1986;ii:939-43.

13 Moreau R, Lec SS, Hadengue A, Braillon A, Lebrec D. Hemodynamic effects of a clonidine-induced decrease in sympathetic tone in patients with irrhosis. Hepatology 1987:7:149-54

14 Grossman a Stubbs WA Gaillard RC, Delitala G, Rees LH, Besser GM Studies of the opiate control of prolactin, GH and TSH. Clin Endocrinol Oxf 1981;14:381-6.

15 Resnick RB, Kestenbaum RS, Washton A, Poole D. Naloxone-precipitated withdrawal: a method for rapid induction onto naltrexone. Clin Pharmaco Ther 1977;21:409-13.

16 Cornford EM, Braun LD, Crane PD, Oldendorf WH. Blood-brain barrier restriction of peptides and the low uptake of enkephalins. Endocrinology 1978; 103:1297-303

17 Kastin AJ, Nissen C. Schally AV, Coy DH. Blood-brain barrier, half-time disappearance and brain distribution for labelled enkephalin and a potent analog. Brain Res Bull 1976:1:583-9.
18 Rapoport SI, Klee WA, Pettigrew KD, Ohno K. Entry of opioid peptides into the central nervous system. Science 1980;207:84-6.

19 Banks WA, Kastin AJ, Fischman AJ, Coy DH, Strauss SL. Carrier-mediated transport of enkephalins and N-tyr-MIF-1 across blood-brain barrier. Am J Physiol 1986;251:E477-82.

20 Zlokovic BV, Lipovac MN, Begley DJ, Davson H, Rakic L. Transport of leucine-enkephalin across the blood-brain barrier in the perfused guinea pig brain. F Neurochem 1987;49:310-5.

21 Wei E, Loh H. Physical dependence on opiate-like peptides. Science 1976;193:1262-3.

22 Gmerek DE, Woods JH. Kappa receptor mediated opioid dependence in rhesus monkeys. Life Sci 1986;39:987-92.

23 Corbett AD, Paterson SJ, McNight AT, Magnan J, Kosterlitz HW. Dynorphin 1-8 and dynorphin 1-9 are ligands for the $x$-subtype of opiate receptor. Nature 1982;299:79-81.

24 Hersh LB. Reaction of opioid peptides with neutral endopeptidase ("enkephalinase"). 7 Neurochem 1984;43:487-93.

25 Yamasaki Y, Shimamura O, Kizu A, Nakagawa M, Ijichi H. IgE-mediated ${ }^{14} \mathrm{C}$-serotonin release from rat mast celis modulated by morphine and endorpins. Life $S_{c i} 1982 \cdot 31 \cdot 4718$.

26 Casale TB, Bowman $S$, Kaliner M. Induction of human cutaneous mast cell degranulation by opiates and endogenous opioid peptides: evidence for opiate and non-opiate receptor participation. I Allergy Clin Immuno 1984:73:775-81.

27 Shanahan F, Lee TDG, Bienenstock J, Befus AD. The influence of endorphins on peritoneal and mucosal mast cell secretion. $\mathcal{F}$ Allergy Clin Immunol 1984;74:499-504.

28 Sugiyama $\mathrm{K}$, Furata $\mathrm{H}$. Histamine release induced by dynorphin-(1-13) from rat mast cells. Fapanese fournal of Pharmacologv 1984;35:247-52.

29 Shapiro JM, Smith H, Schaffner F. Serum bilirubin: a prognostic factor in primary biliary cirrhosis. Gut 1979;20:137-40.

30 Dixon R, Howes J, Gentile J, et al. Nalmefene: intravenous safety and kinetics of a new opioid antagonist. Clin Pharmacol Ther 1986;39:49-53.

(Accepted 4 November 1988

\title{
Computerised updating of clinical summaries: new opportunities for clinical practice and research?
}

Department of Medicine, King's College School of Medicine and Dentistry, Denmark Hill, London SE5 8RX

D E Huw Llewelyn, MD, senior lecturer

David L Ewins, MRCP, registrar

Jackie Horn, secretarial research assistant Alan M McGregor, MD, professor of medicine

Paxton Green Health Centre, London SE21 8AU Tyrrell G R Evans, MRCGP, general practitioner

Correspondence to: Dr Llewelyn.

\section{E Huw Llewelyn, David L Ewins, Jackie Horn, Tyrrell G R Evans, Alan M McGregor}

\begin{abstract}
A new type of clinical summary, produced by copying standard descriptions of diseases on to a computer screen and editing them to match a patient's findings and diagnoses, was updated and reprinted as the patient's condition changed in the ward or as an outpatient. When this method was used to produce typed medical discharge summaries over a three month period, 73 out of $91(80 \%)$ were sent out within a week after discharge compared with five out of $56(9 \%)$ conventionally typed summaries received in a single general practice.

Even completely new computerised summaries are quicker for the secretary to produce than conventional summaries, and the computerised summaries are designed to be scanned rapidly for relevant information. They can also be used to collect data automatically for research, clinical audit, and resource management.
\end{abstract}

\section{Introduction}

Few computer systems have been designed to help hospital doctors and secretaries avoid tedious repetition and to save time when clinic letters and discharge summaries are being dictated and typed. Word processing software can reduce the amount of dictating and typing required by allowing the copying of standard paragraphs into a document, but this approach has been applied to medicine only in a limited way, for copying simple phrases into standard letters. This technique is difficult to apply when there are many diagnoses because the conventional letter or summary does not give the findings and the management of each diagnosis together in single blocks of text that can be transferred conveniently. Instead, the details of a single diagnosis are dispersed in different sections describing the history, examination, and investigations. This problem can be overcome by using a special format for the clinical summary and for the standard text.

\section{Methods}

The software system used in the study was an application of Lotus Symphony run on an IBM PC AT microcomputer. The format of the summary was based on three columns: findings, diagnoses, and management. Each column was divided into blocks of text, which were aligned horizontally and represented a single diagnosis (table I). The summary was drafted by copying the standard blocks of text from a library of entries held on a computer disk into the summary, which was then printed out. The entries on this printout were then edited by the doctor until they represented the patient's details (table II) and the changes were entered into a computer file by the secretary.

The doctor was able to check for clinical omissions and other errors as he edited the summary. This could be done while the patient was still in the ward, when any missing information was easily available. The consultant, other doctors, nurses, paramedical staff, and students caring for the patient could thus refer to the summary and comment or ask about its contents. When the patient was seen in a follow up clinic or readmitted the summary could be updated and reprinted.

\section{ASSESSMENT OF THE SYSTEM}

The new summaries were produced for all routine and emergency patients admitted to a medical department under the care of two consultant physicians over three months. The time from discharge of the patient to completion of the final summary was recorded in three different groups of patients: those admitted under the care of the two consultants who were using the new system; those admitted during the same period 
TABLE I-Standard block of text in three columns before editing

\begin{tabular}{|c|c|c|}
\hline Findings & Diagnosis & Management \\
\hline $\begin{array}{l}\text { Central chest pain } \\
\text { radiating to neck, jaw, } \\
\text { down left arm(s) lasting } \\
>30 \text { minutes, associated } \\
\text { anxiety, nausea, vomiting, } \\
\text { transient rise in } \\
\text { temperature. } \\
\text { ECG: Q wave, raised ST } \\
\text { segment, inverted T-waves } \\
\text { in leads V1-V5, AVL, S1, } \\
\text { AVR S2, AVF, S3. Rise and } \\
\text { fall in creatine } \\
\text { phosphokinase, aspartate } \\
\text { transaminase, lactate } \\
\text { dehydrogenase. }\end{array}$ & $\begin{array}{l}\text { MYOCARDIAL } \\
\text { INFARCTION: ACUTE } \\
\text { <ICD9=410>/OLD } \\
\text { <ICD9=412>/ ANTERIOR/ } \\
\text { POSTERIOR/INFERIOR/ } \\
\text { SEPTAL/LATERAL } \\
\text { Caused by coronary } \\
\text { atherosclerosis, severe } \\
\text { hypotension. Complicated } \\
\text { by acute left ventricular } \\
\text { failure, supra/ventricular } \\
\text { ectopics /tachycardia / } \\
\text { fibrillation, 1st / } 2 \text { nd /3rd } \\
\text { degree heart block, } \\
\text { cardiogenic shock. }\end{array}$ & $\begin{array}{l}\text { Admission to medical } \\
\text { ward/coronary care unit. } \\
28-35 \% \text { oxygen. IV cannula, } \\
\text { diamorphine IV for pain, } \\
\text { thrombolytic therapy, } \\
\text { heparin sc, diazepam, beta } \\
\text { blocker, cardiac } \\
\text { monitoring, 4-hourly } \\
\text { observations, long term } \\
\text { beta blocker, antiplatelet } \\
\text { agent, exercise test. }\end{array}$ \\
\hline
\end{tabular}

TABLE II-Sample of patient's record showing edited summary blocks

\begin{tabular}{|c|c|c|}
\hline $\begin{array}{l}\text { Hospital No } \\
\text { Surname } \\
\text { First names } \\
\text { Date of birth }\end{array}$ & $\begin{array}{l}\text { E123456 } \\
\text { Fictitious } \\
\text { Harriet Mary } \\
01.01 .21\end{array}$ & $\begin{array}{l}\text { Last update on: } 29-\text { Sep-88 } \\
\text { at KING'S COLLEGE } \\
\text { HOSPITAL } \\
\text { Checked by: }\end{array}$ \\
\hline $\begin{array}{l}\text { Dept-Ward-Clinic } \\
\text { Consultant }\end{array}$ & $\begin{array}{l}\text { Firm B. Wadd. Endo. T. } \\
\text { Dr DE H Llewelyn }\end{array}$ & $\begin{array}{l}\text { General practitioner: } \\
\text { Dr Roseveare }\end{array}$ \\
\hline Findings & Diagnosis & Management \\
\hline $\begin{array}{l}\text { Central chest pain radiating } \\
\text { down left arm lasting } \\
60 \text { minutes on } 20.9 .88 \text {. } \\
\text { Transient rise in } \\
\text { temperature } 21.9 .88 . ~ E C G \text { : } \\
\text { Q waves, raised ST } \\
\text { segment and inverted T } \\
\text { waves in leads S2, AVF and } \\
\text { S3. Rise and fall in creatine } \\
\text { phosphokinase } 20.9 .88 \text { to } \\
22.9 .88 \text {. }\end{array}$ & $\begin{array}{l}\text { MYOCARDIAL } \\
\text { INFARCTION: ACUTE } \\
\text { INFERIOR <ICD9=410> } \\
\text { Caused by coronary } \\
\text { atherosclerosis, } \\
\text { complicated by acute left } \\
\text { ventricular failure. No } \\
\text { ectopics, tachycardia, atrial } \\
\text { fibrillation, or heart block. }\end{array}$ & $\begin{array}{l}\text { Admission to medical ward } \\
20.9 .88 \text {, discharged } 29.9 .88 \text {. } \\
\text { Given diamorphine IV for } \\
\text { pain, and heparin sc for } \\
3 \text { days. Uneventful } \\
\text { recovery. Review for } \\
\text { complications in medical } \\
\text { outpatients } 19.10 .88 \text {. }\end{array}$ \\
\hline $\begin{array}{l}\text { Orthopnoea. Fine } \\
\text { crepitations at bases. Third } \\
\text { heart sound. CXR: large } \\
\text { heart and "upper lobe vein } \\
\text { dilatation" (21.9.88). All } \\
\text { clinical findings resolved } \\
\text { on 23.9.88. }\end{array}$ & $\begin{array}{l}\text { ACUTE LEFT } \\
\text { VENTRICULAR FAILURE } \\
<\text { ICD } 9=428.1>\text { due to } \\
\text { myocardial infarction. }\end{array}$ & $\begin{array}{l}\text { Frusemide } 40 \mathrm{mg} \text { once } \\
\text { daily to be continued after } \\
\text { discharge and need } \\
\text { reviewed in medical } \\
\text { outpatients on } 19.10 .88 \text {. }\end{array}$ \\
\hline $\begin{array}{l}\text { Full blood count normal, } \\
\text { urea \& elecs normal, liver } \\
\text { function tests, calcium } \\
\text { normal (see reports } \\
21.9 .88 \text { ). }\end{array}$ & $\begin{array}{l}\text { No haematological, renal, } \\
\text { calcium, or hepatic } \\
\text { abnormalities in } \\
\text { September } 1988 .\end{array}$ & $\begin{array}{l}\text { No action. Repeat after } \\
1 \text { year. }\end{array}$ \\
\hline
\end{tabular}

under the care of another consultant in the same department who was not using the new system and whose summaries were all handwritten; and those belonging to a single general practice, for whom discharge summaries had been received by the practice from a number of hospitals over one month.

The time taken by a secretary to produce nine completely new discharge summaries in the new format was compared with that taken to type the same number in a conventional format using an electric typewriter. The conventional summaries were dictated by the same registrar and typed by the same secretary; both were using the new system. The conventional summary was always produced after the new summary had been finished.

\section{Results}

Nine summaries were produced in the new summary table format as well as in conventionally typed format (in which the diagnoses were followed by the history, examination, test results, management, and progress). The average total time taken (in two or three sessions) to produce a summary in the new format was
6.05 minutes (SD 2.53), whereas the same secretary took an average of $13 \cdot 2(4 \cdot 11)$ minutes to produce a conventionally typed summary on an electric typewriter for the same nine patients. The difference was statistically significant $(\mathrm{p}<0 \cdot 001 ; t=7 \cdot 48, \mathrm{df}=8$ ).

The registrar did not use the computer at all; his editing was done on paper copies of the summary during ward rounds or shortly afterwards. He spent an average of about 10 minutes over two or three sessions on each new summary. When a three column summary existed he spent about two minutes on each patient.

Summaries on all 91 patients admitted under the two consultants who used the new system were completed during the study period. The general practitioner of four of these patients was not known. Only 49 of 56 handwritten summaries from the same department were completed during the study period. The general practitioner was not known for 11 of these patients. The 95 summaries received by the general practice were from 12 different hospitals, mainly in south London. Thirty three were from King's College Hospital.

Of the 91 summary tables, 73 were dated within one week after the patient's discharge. Of the 49 handwritten summaries, 16 were dated within one week. Thirty nine of the 95 summaries received by the general practice were handwritten, and 30 of these 39 had been dated within one week after discharge. Only five of the 56 typed summaries had been completed and dated within the week.

\section{Discussion}

This delay for conventional summaries and discharge letters was similar to that described at another group of hospitals. ${ }^{2}$ The new system allowed typed summaries to be sent out as quickly as the handwritten discharge letters that had been received by the general practice and much more quickly than either conventionally typed or hand written summaries from the same department. The computerised system promises to be extremely quick when a three column summary is already available from a patient's previous admissions or clinic visits. When such patients are seen again the drafting and editing of summaries is usually minimal.

Because the new summary can be started while the patient is still in hospital, missing information can more readily be found. A high proportion of the handwritten summaries could not be sent to the practice because the general practitioner's name had not been entered in the patient's notes on admission and the omission was overlooked until after the patient had been discharged.

Efficiency can also be improved in other ways. For example, if the summaries were edited on terminals sited in the ward or in the outpatient department, the system could also be used to produce request forms for tests and prescriptions by copying the relevant information automatically from the summary. The summary could then be regarded as a multipurpose master form. The new summary could be given to patients in accordance with the Data Protection Act 1984 , which would avoid having to prepare a special abstract. Postal delay could be overcome by handing the latest draft of the summary to the patient at discharge with a standard letter to say that the final summary with the outstanding test results would be posted later. ${ }^{3}$ The patient would then be able to give the general practitioner a typed provisional summary at the next consultation. Electronic mail would be another way of improving communication. In future the standard text might be kept constantly up to date by accessing the latest edition of each entry every day by an electronic link to a central source. This could, for 
example, include urgent notices on the side effects of drugs.

The standard text can bring errors and omissions to the attention of the doctor editing it. This might be of value in both undergraduate and postgraduate training; indeed, it would bring new developments to the attention of all doctors as they did their routine paperwork. Senior doctors could influence how summaries are written by modifying the text. Messages could be added, for example, to say that patients with a particular diagnosis should be asked to participate in some clinical study. The text could also be adapted to collect research data by turning the standard entry into a research form. The system is already set up in this way to provide codes from the International Classification of Diseases, ninth revision ${ }^{4}$ (table I); the same can be done for codes from other classification systems, such as diagnosis related groups. Thus, administrative and research data can be collected with little extra effort by using a system which is in itself quicker and less tedious than traditional methods.

We thank Mr Jim Radcliffe and Mr Roger Steer of the Camberwell Health Authority finance department for their support and encouragement. We thank Drs J C French, M Kiln, I L Michell, R W Penny, G Rice, and M P Roseveare of Paxton Green Health Centre for allowing us to examine the summaries arriving at the practice, and Drs K W Pettingale and J F Martin for access to the medical records of their patients.

1 Dunn DC, Dale RF. Combined computer generated discharge documents and surgical audit. Br Med $\mathcal{F}$ 1986;292:816-8.

2 Penney TM. Delayed communication between hospitals and general practitioners: where des the problem lie? Br Med $1988 ; 297: 28$.

3 Sandler DA, Mitchell JRA. Interim discharge summaries: how are they best delived Michell JRA. Inerim discharge summaries: how an

4 World Health Organisation. International classification of diseases, injuries and causes of death. 9th revision, 1975. Geneva: WHO, 1977.

(Accepted 29 September 1988

\title{
Dose response relation to oral theophylline in severe chronic obstructive airways disease
}

\author{
H Chrystyn, B A Mulley, M D Peake
}

\section{Abstract}

Objective-To evaluate measurement of the trapped gas volume as a measure of respiratory function in patients with chronic obstructive airways disease and their response to treatment with theophylline.

Design-Patients able to produce consistent results on testing of respiratory function spent two weeks having dosage of theophylline adjusted to give individual pharmacokinetic data. This was followed by random assignment to four consecutive two month treatment periods-placebo and low, medium, and high dose, as assessed by serum concentrations of theophylline. Respiratory function and exercise performance was assessed at the end of each two month period.

Setting-Chest unit in district hospital.

Patients-Thirty eight patients with chronic bronchitis and moderate to severe chronic obstruction to airflow were recruited; 33 aged 53-73 years completed the study.

Interventions-Dosage of oral theophylline increased during two week optimisation period to $800 \mathrm{mg}$ daily unless toxicity was predicted, when $400 \mathrm{mg}$ was given. Targets for the steady state serum theophylline concentrations were $5-10 \mathrm{mg} / \mathrm{l}$ in the low dose period, $10-15 \mathrm{mg} / \mathrm{l}$ in the medium dose, and $15-20 \mathrm{mg} / \mathrm{l}$ in the high dose period.

Endpoints-Respiratory function as measured by

Chest Unit, Pontefract

General Infirmary, West Yorkshire WF8 1PL

$\mathrm{H}$ Chrystyn, PHD, research pharmacist

M D Peake, MRCP, consultant physician

\section{Department of}

Pharmaceutical

Technology, School of

Pharmacy, University of

Bradford, West Yorkshire BD7 1DP

B A Mulley, PHD, reader

Correspondence to:

Dr Peake. volume from 1.841 (SE 0.157) to $1.421(0.152)$, 1 .05 $(0.128)$, and $0.671(0.102)$ during the placebo and low, medium, and high dose treatment periods.
Mean walking distance increased by up to $55.6 \mathrm{~m}$ $(20 \%)$. There was a modest improvement in dyspnoea as the dose of theophylline was increased. Side effects were mostly minor but they became more frequent as the dose was increased.

Conclusion-The fall in trapped gas volume may reflect an improvement in peripheral ventilation (associated with treatment with theophylline) which is less apparent in the more common tests of lung function used in patients with chronic obstructive airways disease.

\section{Introduction}

The assessment of the efficacy of bronchodilator treatment in patients with asthma is fairly straightforward. Simple tests such as peak expiratory flow rate and forced expiratory volume in one second correlate well with symptoms and the clinical response to treatment. In contrast the measurement of response to treatment in "irreversible" chronic obstructive airways disease is more difficult. Improvement of symptoms is common in these patients when measurements such as peak expiratory flow rate and forced expiratory volume in one second remain unchanged. In a small study of patients recovering from an acute exacerbation of chronic obstructive airways disease clinical improvement was accompanied by a fall in functional residual capacity and "trapped gas volume" with negligible changes in peak expiratory flow rate, forced expiratory volume in one second, or forced vital capacity. ${ }^{1}$ Trapped gas volume is the difference between total lung capacity measured by whole body plethysmography and that measured by helium dilution $^{23}$ and probably represents the volume of poorly ventilated areas of the lungs, perhaps best described as a ventilatory "slow space." Falls in trapped gas volume have been reported during recovery from acute severe asthma ${ }^{14}$ and after treatment in the chronic phase. ${ }^{25}$ Reports of deflation of the lungs after inhaled bronchodilators ${ }^{67}$ would also be consistent with a fall in trapped gas volume, though in those studies helium dilution was not used to measure total lung capacity. 